\title{
Inspiring contemporary social work: Latest developments
}

There has been a flurry of international interest of late about the nature and state of leadership in social work (Holosko, 2009; Sullivan, 2016). These discussions inevitably detail lists of transformative personal attributes and capabilities for leaders, but rarely cite the quiet and sustained small acts of leadership derived from writing and sharing ideas about practice, research and social work scholarship. In the knowledge that writing and publishing can be a lonely and often exposing activity for authors, we as an editorial collective both encourage and applaud the contributors to our journal who take the time to explore, question and write about what they are doing.

Contributions to our national journal have historically reported on issues connected with direct practice, research and policy relevant to social work, as well as documenting the development of new conceptualisations for understanding both our discipline and diverse social issues. All of these dimensions are present in this latest edition. Importantly, this edition demonstrates social work's critical engagement with a range of people impacted by political, economic and social conditions such as the homeless, new parents, victims of abuse, immigrants to our country, and practitioners working in the field. These articles come together to contribute to a body of sustained inquiry into the complex social questions that practitioners grapple with, in their day to day work.

The first article in this edition Supporting transition to parenthood in Aotearoa New Zealand reports on research into early parenthood by Irene de Haan. Previous studies in diverse disciplines testify to the crucial role of parenting for fostering positive child outcomes (Krocheck \& Mowder, 2012). Even so, de Haan's research into this significant life transition documents the tumultuous experiences for both mothers and fathers and identifies the important gaps in service provision experienced by new parents. Ways in which practitioners might promote awareness and provide greater assistance during this transition to parenthood are discussed.

On an entirely different note we turn to our history. David McCullough, in the Jefferson lecture (2003) related "To me, history ought to be a source of pleasure. It isn't just part of our civic responsibility. To me, it's an enlargement of the experience of being alive, just the way literature or art or music is." In the second article of this edition, Sonya Hunt prompts readers to both honour the efforts of social workers who have gone before, as well as learn some lessons from the history of social work. In much the same way as McCullough relates that history is part of being alive, The social work professionalisation project in Aotearoa New Zealand: The dream, both records the early history and development of social work in this country and reminds readers that our history unfolds day by day and that we are all caretakers of that heritage. Key turning points in this history are discussed providing evidence of the strength of collaboration to establish social work in this country, while also documenting significant challenges. Hunt's account is characterised by a dynamic $\mathrm{ebb}$ and flow of political social influences, along with acknowledging the individual and collective efforts to establish and sustain the profession in Aotearoa New Zealand. We note from Hunt's article that the establishment of the national journal in 1965 was one of the milestone markers in the history of professionalisation of social work in this country.

Meanwhile, urgent and persistent harm related to issues of poverty and
AOTEAROA

NEW ZEALAND SOCIAL WORK 28(3), 1-3. 
marginalisation of people is ever present in the forefront of contemporary social work practice. In our own country, the tragic slaying of Work and Income New Zealand staff in Ashburton on 1st September 2014 highlighted the risky and complex nature of client presentations to WINZ offices. In the third article of this edition, we publish an Australian research account about the influence of social work practice within Centrelink, the organisation responsible for income maintenance in that country. In $A n$ adventurous journey: Social workers guiding customer service workers on the welfare frontline Hall, Boddy and Chenoweth report on how the support and education resources provided by social workers to customer service workers in Centrelink impacted positively upon service delivery within that organisation. This contribution showcases an example of where social work practice at the meso level can promote social change within a large bureaucracy. Formal evaluation of this initiative illustrates the evidence base for this effective social work intervention.

Moving from Australia to Scotland, David McKendrick provides a critical analysis of the named person scheme within child protection legislation in that country. In Crafting the Society of Control, McKendrick draws upon theory from Deleuze (1992) to explore notions of surveillance and late modernity and the implications for social work practice. While this article provides a critique of the named person scheme it also contributes to furthering the conceptualisation of child protection practice through theoretical examination and policy analysis. New ideas about practice are promoted through discussing the skills, processes and tasks associated with facilitating an innovative intervention, development of theory occurs through extending current conceptual thinking and applying this analysis to emerging developments in policy and practice.

Continuing the focus on child protection practice, Shirley Jülich and Eileen Oak critically examine secrecy, silence and reluctance to disclose in the context of child sexual abuse. In Does grooming facilitate the development of Stockholm Syndrome? The Social Work Practice Implications, the grooming process in child sexual abuse is considered as a facilitator of the development of Stockholm syndrome; and the syndrome may have a role in maintaining silence about sexual abuse through to adulthood. Of particular interest in this article is the exploration of how Stockholm syndrome may impact child protection professionals and either provide safety, or increase risk, for the child.

We then turn to look at immigration. Immigration is a hotly debated topic in Aotearoa New Zealand and around the world with positive views highlighting the many benefits that arise from countries having a diverse population, and negative views often being based on stereotypes (Lyons et al. 2011). In their article, Attending to immigrants' everyday activities: A new perspective on ensuring Asian immigrants' quality of life, Hagyun Kim and Clare Hocking acknowledge that Asian immigrants to Aotearoa New Zealand face a range of challenges that can have a negative impact on families and can lead to the marginalisation of Asian communities. The authors pay attention to the role that social workers can play in enhancing the quality of life for Asian immigrants. Drawing on occupational science, the article explores how an occupational framework can provide social workers with a greater understanding of how Asian immigrants do immigration; that is, how occupations play a mediating role in helping immigrants to connect with others and adjust to life in a new society.

In the next article, In search of 'home' for wellness: Mental health social workers' views on homelessness in mental health, Shoichi Isogai reports on research that explored the views of mental health social workers as to how mental health clients experienced homelessness. While the research was focused on homelessness in Auckland, the issues of homelessness is pertinent to Aotearoa New Zealand in general. Isogai, 
makes the point that users of mental health services face a range of individual and structural factors that act as barriers to finding a home; and in particular, structural issues make homelessness an enduring issue for users of mental health services. On the basis of the research findings, Isogai makes suggestions for practice that capture the problem solving, empowerment and advocacy components of social work (International Federation of Social Workers, 2014).

Finally, Shirley-Ann Chinnery reminds social workers of the importance of attachment theory and shares some interesting social work history. The significance of social work practice knowledge in the evolution of attachment theory is a disciplinary connection little known to many social work practitioners. This article, Social work's fingerprint on the evolution of attachment theory: Some essential knowledge for care practice, seeks to remind care practice social workers specifically of this association along with a very useful discussion of the ongoing utility of attachment and the concept of the internal working model in foster care practice.

\section{References}

Deleuze, G. (1992). Postscript on societies of control. October, 59, (Winter), 3-7.

Holosko, M. (2009). Social work leadership: Identifying core attributes. Journal of Human Behavior in the Social Environment, 19(4), 448-459. http://dx.doi. org/10.1080/10911350902872395

International Federation of Social Workers. (2014). Global definition of social work. Retrieved from http://ifsw.org/ policies/definition-of-social-work/

Krocheck, R., \& Mowder, B. (2012).Parenting infants: Relative Importance of parenting characteristics and related behaviors. Journal of Early Childhood and Infant Psychology, 8, 21-34.

Lyons, A. C., Madden, H., Chamberlain, K., \& Carr, S. (2011), 'It's not really us discriminating against immigrants, it's more telling people how to fit in': Constructing the nation in immigration talk in New Zealand. Journal of Community and Applied Social Psychology, 21, 14-27. doi: 10.1002/casp.1051

McCullough, D. (2003). Jefferson lecture. Retrieved from https://www.neh.gov/about/awards/jefferson-lecture/ david-mccullough-lecture

Sullivan, W. (2016). Leadership in social work: Where are we? Journal of Social Work Education, 52 (sup1), S51-S61. http://dx.doi.org/10.1080/10911350902872395

Jane Maidment and Yvonne Crichton-Hill, University of Canterbury, New Zealand 